\title{
Artificial Intelligence in Patients with Congenital Heart Disease: Where Do We Stand?
}

The authors have performed a literature search of how state-of-theart imaging diagnoses for congenital heart disease are taking place with the help of artificial intelligence (AI). There is a clinical unmet need for the use of $\mathrm{Al}$ in congenital heart disease, and a joint effort is needed to spread Al knowledge and applications in the medical field to improve

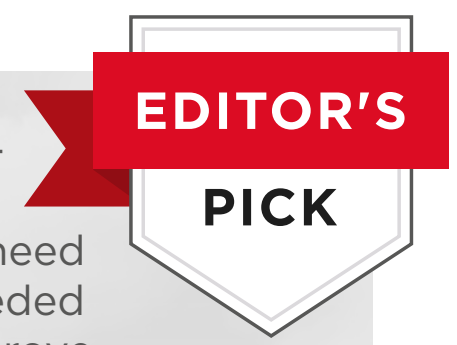
diagnosis, treatment, and outcomes for patients. This review gives an overview of Al usage in diagnostic imaging, electrocardiograms, and clinical diagnosis in patients with congenital heart disease.

Authors:

*Marinka D. Oudkerk Pool,, ${ }^{1,2}$ Dirkjan Kauw, ${ }^{1,2}$ Hidde Bleijendaal, ${ }^{1}$ Barbara J.M. Mulder, ${ }^{1}$ Yigal Pinto, ${ }^{1}$ Berto J. Bouma, ${ }^{1}$ Michiel M. Winter ${ }^{1}$

1. Department of Cardiology, Amsterdam University Medical Center, University of Amsterdam, Amsterdam, the Netherlands

2. Netherlands Heart Institute, Utrecht, the Netherlands

*Correspondence to m.d.oudkerkpool@amsterdamumc.nl

Disclosure: $\quad$ The authors have declared no conflicts of interest.

Received: $\quad 17.02 .2020$

Accepted: $\quad 30.03 .2020$

Keywords: $\quad$ artificial intelligence $(\mathrm{Al})$, congenital heart disease (CHD), machine learning (ML), deep learning (DL).

Citation: $\quad$ EMJ Cardiol. 2020;8[1]:70-81.

\begin{abstract}
Life expectancy of patients with congenital heart disease (CHD) has increased in recent decades; however, late complications remain frequent and difficult to predict. Progress in data science has spurred the development of decision support systems and could aid physicians in predicting clinical deterioration and in the management of CHD patients. Newly developed artificial intelligence (AI) algorithms have shown performances comparable to humans in clinical diagnostics using statistical and computational algorithms and are expected to partly surpass human intelligence in the near future. Although much research on Al has been performed in patients with acquired heart disease, little data is available with respect to research on Al in patients with CHD. Learning algorithms in patients with CHD have shown to be promising in the interpretation of ECG, cardiac imaging, and the prediction of surgical outcome. However, current learning algorithms are not accurate enough to be implemented into daily clinical practice. Data on Al possibilities remain scarce in patients with CHD, and studies on large data sets are warranted to increase sensitivity, specificity, accuracy, and clinical relevance of these algorithms.
\end{abstract}




\section{INTRODUCTION}

Improved medical treatment and surgical techniques has caused the life expectancy of patients with congenital heart disease (CHD) to be significantly prolonged. ${ }^{1-3}$ As these patients reach adulthood, late complications such as arrhythmias and congestive heart failure occur," resulting in reduced quality of life and life expectancy. ${ }^{4}$ Furthermore, these complications often result in unscheduled hospital visits or even emergency admissions. ${ }^{3,5-7}$ Although visits to the outpatient clinic are frequent, it remains difficult to predict and prevent clinical deterioration.

With the introduction of the electronic medical record and the ability to digitally store data for diagnostic modalities, such as ECG and echocardiography, large amounts of patient data have been generated over the past few decades. Using machine learning (ML) or deep learning (DL) for the analysis of these data has been a topic of interest for some years. Progress in data science has spurred the development of decision support systems which can aid physicians in the management of CHD patients and therapeutic decision making. ${ }^{4,8,9}$ Newly developed algorithms perform as well as humans in clinical diagnostics using statistical and computational algorithms to perform recognition, classification, and learning tasks, and are expected to outperform humans in the near future. ${ }^{10,11}$

Used in this context, artificial intelligence (AI) is an umbrella term for the use of computers to model intelligent behaviour. The terms 'neural networks,' DL, and ML are technical concepts that fall under this umbrella but are confusingly used interchangeably with the term $\mathrm{Al}$ in the literature. This review will focus on $M L$ and $D L$. Learning algorithms learn from data given as an input, also called the training dataset. The algorithm then gets tested on a so-called test or validation dataset, which contains new unseen data. ML, specifically, refers to algorithms that can 'learn' patterns from training data and then use the learned patterns to classify previously unseen data. ${ }^{12} \mathrm{DL}$ algorithms have an extra hidden layer, which allows them to automatically detect important features from the data, while in $M L$ algorithms, the features need to be provided manually.,13
Although several Al studies have been performed in patients with CHD over the past few years, data are limited compared to data in patients with acquired heart disease. .,8,9,13-16 Considering the propensity of CHD patients for developing arrhythmias and heart failure, the predictive abilities of the Al algorithms could prove to be lifesaving. Therefore, the aim of this review is to provide an overview of studies investigating the potential of $\mathrm{Al}$ algorithms with respect to the various imaging modalities in patients with CHD.

\section{METHODS}

\section{Literature Search}

Medline ${ }^{\circledR}$ (Northfield, Illinois, USA) and EMBASE (Elsevier, Amsterdam, the Netherlands) were used to search for studies published up to $9^{\text {th }}$ August 2019. The search was developed iteratively for synonyms of 'congenital heart disease,' ML, DL, and $\mathrm{Al}$, both controlled vocabulary (Medical Subject Headings [MeSH]) and free-text words. Nonhuman studies, case reports, biomarker studies, and reviews were excluded. The reference list and cited articles were checked for additional references.

\section{Selection of Studies}

Studies were included if they applied Al algorithms for diagnostics (heart sound, echocardiography, MRI, CT, electrocardiogram analysis, and classification/prediction models, for example) in CHD patients. Since the terms AI, $D L$, and $M L$ are used interchangeably, all three terms were included in this review. All potential articles were read in full by two authors (Ms Marinka D. Oudkerk Pool and Mr Dirkjan Kauw). Disagreements concerning eligibility were resolved by discussion.

\section{Extraction of Data}

The extracted data from each paper were author, publication year, total number of patients (both training and test set), patient population, data used for analysis (input data in the algorithm), primary outcome (goal of the study), the used Al algorithm, and accuracy of the proposed Al algorithm. For comparison between the different techniques the sensitivity (SE), specificity (SP), and accuracy were used. 


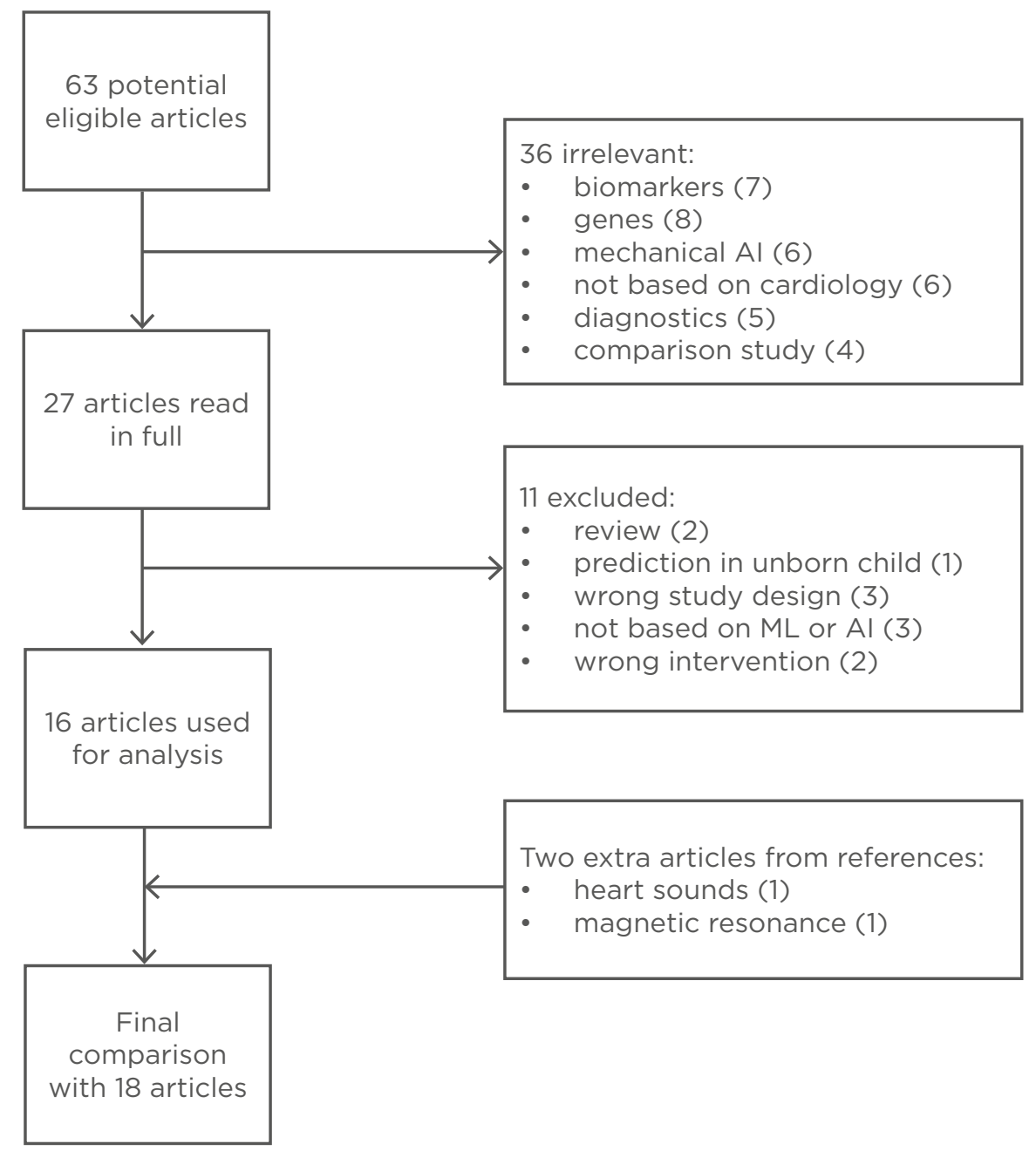

Figure 1: Flow diagram of search query.

Al: artificial intelligence; ML: machine learning.

Accuracy is defined as the number of correctly classified results compared to the 'true' value (either positive or negative), as assessed by the gold standard technique.

True positive (TP) is the proportion of actual positives that are correctly identified as such. True negative (TN) is the proportion of actual negatives correctly identified as such. False positive (FP) is a negative value identified as a positive value, and false negative $(F N)$ is a positive value identified as a negative value. SE, SP, and accuracy can be defined using equations: ${ }^{17-20}$

$$
\begin{aligned}
& \mathrm{SE}=100 \times \frac{\mathrm{TP}}{\mathrm{TP}+\mathrm{FN}} \\
& \mathrm{SE}=100 \times \frac{\mathrm{TP}}{\mathrm{TN}+\mathrm{FP}} \\
& \text { accuracy }=100 \times \frac{\mathrm{TP}+\mathrm{TN}}{\mathrm{TP}+\mathrm{TN}+\mathrm{FP}+\mathrm{FN}}
\end{aligned}
$$

\section{RESULTS}

In total, 63 articles were potentially eligible for this review after removing duplicates. Forty-eight articles were considered irrelevant because they focussed on biomarkers, genes, mechanical Al, were not based on cardiology (either neurology or mechanical ventilation), diagnostics (over the phone or medication), or comparison study in which two or more imaging modalities were compared. Twenty-seven articles were read in full, after which an additional 11 articles were excluded. Two additional articles were selected by going through the references. The final analysis consisted of 18 articles (Figure 1).

Topics of these studies included analyses of cardiac imaging modalities (echocardiography, $M R I), E C G$, and clinical prediction models using Al algorithms. 
Table 1: Selected articles.

\begin{tabular}{|c|c|c|c|c|c|c|c|c|}
\hline $\begin{array}{l}\text { First author } \\
\text { (year) }\end{array}$ & $\begin{array}{l}\mathrm{n} \\
\text { (training } \\
\text { set) }\end{array}$ & $\begin{array}{l}\mathrm{n} \\
\text { (test } \\
\text { set) }\end{array}$ & $\begin{array}{l}\text { Patient } \\
\text { population }\end{array}$ & $\begin{array}{l}\text { Category } \\
\text { for } \\
\text { analysis }\end{array}$ & $\begin{array}{l}\text { Data used for } \\
\text { analysis }\end{array}$ & $\begin{array}{l}\text { Primary } \\
\text { outcome }\end{array}$ & $\begin{array}{l}\text { Learning } \\
\text { algorithm }\end{array}$ & $\begin{array}{l}\text { Accuracy } \\
(\%)\end{array}$ \\
\hline $\begin{array}{l}\text { Elgendi et } \\
\text { al. }{ }^{21}(2015)\end{array}$ & \multicolumn{2}{|c|}{$\begin{array}{l}\text { 27. Unclear how } \\
\text { data has been } \\
\text { split. }\end{array}$} & $\begin{array}{l}\text { Patients } \\
\text { who were } \\
\text { undergoing } \\
\text { right heart } \\
\text { catheterisation }\end{array}$ & $\begin{array}{l}\text { Heart } \\
\text { sound }\end{array}$ & $\begin{array}{l}\text { Heart sounds } \\
\text { measured } \\
\text { with } 3 M^{\top M} \\
\text { Littmann }^{\circledast} \\
3200 \text { Elec- } \\
\text { tronic Steth- } \\
\text { oscope* }\end{array}$ & $\begin{array}{l}\text { Recorded } \\
\text { heart } \\
\text { sounds to } \\
\text { distinguish } \\
\text { subjects } \\
\text { with PAH }\end{array}$ & $\begin{array}{l}\text { Linear } \\
\text { discriminant } \\
\text { analysis }\end{array}$ & $\begin{array}{l}\text { SE: } 92.86 \\
\text { SP: } 92.31\end{array}$ \\
\hline $\begin{array}{l}\text { Gharehbaghi } \\
\text { et al. }{ }^{22}(2015)\end{array}$ & \multicolumn{2}{|c|}{$\begin{array}{l}\text { 50. Unclear how } \\
\text { data has been } \\
\text { split. }\end{array}$} & $\begin{array}{l}\text { Twenty- } \\
\text { eight healthy } \\
\text { children and } 22 \\
\text { children with } \\
\text { BAV }\end{array}$ & $\begin{array}{l}\text { Heart } \\
\text { sound }\end{array}$ & $\begin{array}{l}\text { Heart sounds } \\
\text { measured } \\
\text { with Medit- } \\
\text { ron Electron- } \\
\text { ic Stetho- } \\
\text { scope }^{+}\end{array}$ & $\begin{array}{l}\text { Develop } \\
\text { algorithm } \\
\text { for detecting } \\
\text { BAV in } \\
\text { children }\end{array}$ & $\begin{array}{l}\text { Support } \\
\text { vector } \\
\text { machine }\end{array}$ & $\begin{array}{l}72.9 \\
\text { Practitioner: } \\
71.60\end{array}$ \\
\hline $\begin{array}{l}\text { Gharehbaghi } \\
\text { et al. } .^{9}(2017)\end{array}$ & \multicolumn{2}{|c|}{$\begin{array}{l}\text { 90. Unclear how } \\
\text { data has been } \\
\text { split. }\end{array}$} & $\begin{array}{l}\text { Fifty-five } \\
\text { healthy } \\
\text { children and } 35 \\
\text { children with } \\
\text { BAV }\end{array}$ & $\begin{array}{l}\text { Heart } \\
\text { sound }\end{array}$ & $\begin{array}{l}\text { Heart sounds } \\
\text { measured } \\
\text { with Medit- } \\
\text { ron Electron- } \\
\text { ic Stetho- } \\
\text { scope }\end{array}$ & $\begin{array}{l}\text { Detecting } \\
\text { BAV, healthy, } \\
\text { or MR from } \\
\text { heart sound }\end{array}$ & $\begin{array}{l}\text { Combination } \\
\text { of hidden } \\
\text { Markolov } \\
\text { model and } \\
\text { support } \\
\text { vector } \\
\text { machine } \\
\end{array}$ & 86.4 \\
\hline $\begin{array}{l}\text { Elgendi et } \\
\text { al. }^{23}(2018)\end{array}$ & \multicolumn{2}{|c|}{$\begin{array}{l}\text { 60. Unclear how } \\
\text { data has been } \\
\text { split. }\end{array}$} & $\begin{array}{l}\text { Patients } \\
\text { who were } \\
\text { undergoing } \\
\text { right heart } \\
\text { catheterisation }\end{array}$ & $\begin{array}{l}\text { Heart } \\
\text { sound }\end{array}$ & $\begin{array}{l}\text { Heart sounds } \\
\text { measured } \\
\text { with 33M } \\
\text { Littmann } \\
3200 \text { Elec- } \\
\text { tronic Steth- } \\
\text { oscope }\end{array}$ & $\begin{array}{l}\text { Recorded } \\
\text { heart } \\
\text { sounds to } \\
\text { distinguish } \\
\text { subjects } \\
\text { with PAH }\end{array}$ & $\begin{array}{l}\text { Linear } \\
\text { discriminant } \\
\text { analysis }\end{array}$ & $\begin{array}{l}\text { SE: } 84.00 \\
\text { SP: } 88.57\end{array}$ \\
\hline $\begin{array}{l}\text { DeGroff et } \\
\text { al. }^{24}(2001)\end{array}$ & \multicolumn{2}{|c|}{$\begin{array}{l}69 \text { used for both } \\
\text { training and } \\
\text { validation }\end{array}$} & $\begin{array}{l}\text { Paediatric } \\
\text { patients }\end{array}$ & $\begin{array}{l}\text { Heart } \\
\text { sound }\end{array}$ & $\begin{array}{l}\text { Heart sounds } \\
\text { measured } \\
\text { with Cam- } \\
\text { bridge Heart } \\
\text { Sound Micro- } \\
\text { phone }\end{array}$ & $\begin{array}{l}\text { Distinguish } \\
\text { between } \\
\text { innocent and } \\
\text { pathological }\end{array}$ & $\begin{array}{l}\text { Artificial } \\
\text { neural } \\
\text { network }\end{array}$ & $\begin{array}{l}\text { SE: } 100.00 \\
\text { SP: } 100.00\end{array}$ \\
\hline $\begin{array}{l}\text { Sepehri et } \\
\text { al. }{ }^{25} \text { (2009) }\end{array}$ & 60 & 60 & $\begin{array}{l}\text { Heart sounds } \\
\text { from database } \\
\text { (both healthy } \\
\text { and with } \mathrm{CHD} \text { ) }\end{array}$ & $\begin{array}{l}\text { Heart } \\
\text { sound }\end{array}$ & $\begin{array}{l}\text { Phonocardi- } \\
\text { ogram and } \\
\text { electrocardi- } \\
\text { ogram }\end{array}$ & $\begin{array}{l}\text { Identifying } \\
\text { children with } \\
\text { congenital } \\
\text { heart } \\
\text { disease }\end{array}$ & $\begin{array}{l}\text { Artificial } \\
\text { neural } \\
\text { network }\end{array}$ & 93.6 \\
\hline $\begin{array}{l}\text { Thompson } \\
\text { et al. }{ }^{26} \text { (2018) }\end{array}$ & \multicolumn{2}{|c|}{$\begin{array}{l}603 . \text { Unclear } \\
\text { how data has } \\
\text { been split. }\end{array}$} & $\begin{array}{l}\text { Heart sounds } \\
\text { from database } \\
\text { (John Hopkins } \\
\text { Outpatient } \\
\text { Center, } \\
\text { Baltimore, } \\
\text { Maryland) }\end{array}$ & $\begin{array}{l}\text { Heart } \\
\text { sound }\end{array}$ & $\begin{array}{l}\text { Heart sounds } \\
\text { recorded } \\
\text { with an elec- } \\
\text { tronic steth- } \\
\text { oscope with } \\
\text { correspond- } \\
\text { ing ECG }\end{array}$ & $\begin{array}{l}\text { Distinguish } \\
\text { between } \\
\text { innocent and } \\
\text { pathological }\end{array}$ & Not specified & 88 \\
\hline $\begin{array}{l}\text { Bhatikar et } \\
\text { al. }{ }^{27}(2004)\end{array}$ & \multicolumn{2}{|c|}{$\begin{array}{l}\text { 241. Unclear how } \\
\text { data has been } \\
\text { split. }\end{array}$} & $\begin{array}{l}\text { Heart sounds } \\
\text { from database } \\
\text { (The Children's } \\
\text { Hospital, } \\
\text { Denver, } \\
\text { Colorado) }\end{array}$ & $\begin{array}{l}\text { Heart } \\
\text { sound }\end{array}$ & $\begin{array}{l}\text { Heart sounds } \\
\text { from a } \\
\text { microphone } \\
\text { optimised for } \\
\text { low frequen- } \\
\text { cies }\end{array}$ & $\begin{array}{l}\text { Diagnosis } \\
\text { of heart } \\
\text { murmurs in } \\
\text { paediatrics }\end{array}$ & $\begin{array}{l}\text { Artificial } \\
\text { neural } \\
\text { network }\end{array}$ & $\begin{array}{l}\text { SE: } 83.00 \\
\text { SP: } 90.00\end{array}$ \\
\hline
\end{tabular}


Table 1 continued

\begin{tabular}{|c|c|c|c|c|c|c|c|c|}
\hline $\begin{array}{l}\text { First author } \\
\text { (year) }\end{array}$ & $\begin{array}{l}n \\
\text { (training } \\
\text { set) }\end{array}$ & $\begin{array}{l}\mathrm{n} \\
\text { (test } \\
\text { set) }\end{array}$ & $\begin{array}{l}\text { Patient } \\
\text { population }\end{array}$ & $\begin{array}{l}\text { Category } \\
\text { for } \\
\text { analysis }\end{array}$ & $\begin{array}{l}\text { Data used for } \\
\text { analysis }\end{array}$ & $\begin{array}{l}\text { Primary } \\
\text { outcome }\end{array}$ & $\begin{array}{l}\text { Learning } \\
\text { algorithm }\end{array}$ & $\begin{array}{l}\text { Accuracy } \\
(\%)\end{array}$ \\
\hline $\begin{array}{l}\text { Sepehri et } \\
\text { al. }^{28}(2016)\end{array}$ & 134 & 129 & $\begin{array}{l}\text { Children } \\
\text { referred to the } \\
\text { hospital }\end{array}$ & $\begin{array}{l}\text { Heart } \\
\text { sound }\end{array}$ & $\begin{array}{l}\text { Phonocardi- } \\
\text { ogram and } \\
\text { electrocardi- } \\
\text { ogram }\end{array}$ & $\begin{array}{l}\text { Identifying } \\
\text { children with } \\
\text { congenital } \\
\text { heart } \\
\text { disease }\end{array}$ & Arash-Band & 87.45 \\
\hline $\begin{array}{l}\text { Diller et al. }{ }^{4} \\
\text { (2018) }\end{array}$ & 159 & 40 & $\begin{array}{l}\text { Patients } \\
\text { undergoing } \\
\text { routine } \\
\text { transthoracic } \\
\text { examinations }\end{array}$ & $\begin{array}{l}\text { Ultra- } \\
\text { sound }\end{array}$ & $\begin{array}{l}\text { Echocardio- } \\
\text { graphic data }\end{array}$ & $\begin{array}{l}\text { Discriminate } \\
\text { between } \\
\text { patients with } \\
\text { TGA after } \\
\text { atrial switch } \\
\text { operation, } \\
\text { patients } \\
\text { with ccTGA } \\
\text { and normal } \\
\text { controls }\end{array}$ & $\begin{array}{l}\text { Convolution } \\
\text { neural } \\
\text { network }\end{array}$ & 98 \\
\hline $\begin{array}{l}\text { Pereira et } \\
\text { al. }{ }^{16}(2017)\end{array}$ & 163 & 91 & $\begin{array}{l}\text { Boston } \\
\text { Children's } \\
\text { Hospital } \\
\text { database }\end{array}$ & $\begin{array}{l}\text { Ultra- } \\
\text { sound }\end{array}$ & $\begin{array}{l}\text { Echocardio- } \\
\text { graphic data }\end{array}$ & $\begin{array}{l}\text { Detecting } \\
\text { CoA in } \\
\text { newborns } \\
\text { via } \\
\text { ultrasound }\end{array}$ & $\begin{array}{l}\text { Support } \\
\text { vector } \\
\text { machine }\end{array}$ & $\begin{array}{l}\text { Not } \\
\text { mentioned }\end{array}$ \\
\hline $\begin{array}{l}\text { Neukamm et } \\
\text { al. }^{29}(2013)\end{array}$ & \multicolumn{2}{|c|}{$\begin{array}{l}\text { 30. Unclear } \\
\text { about split } \\
\text { between sets. }\end{array}$} & $\begin{array}{l}\text { Patients with } \\
\text { Tetralogy of } \\
\text { Fallot after } \\
\text { pulmonary } \\
\text { valve } \\
\text { replacement }\end{array}$ & $\begin{array}{l}\text { Ultra- } \\
\text { sound }\end{array}$ & $\begin{array}{l}\text { End-diastol- } \\
\text { ic volume, } \\
\text { end-systolic } \\
\text { volume, and } \\
\text { ejection frac- } \\
\text { tion }\end{array}$ & $\begin{array}{l}\text { Volumetric } \\
\text { assessment } \\
\text { compared } \\
\text { to gold } \\
\text { standard } \\
\text { MRI }\end{array}$ & $\begin{array}{l}\text { Knowledge- } \\
\text { based }\end{array}$ & $\begin{array}{l}\text { EDV; SE: } \\
\text { 100.00, SP: } \\
86.00 \\
\text { ESV; SE: } \\
\text { 78.00, SP: } \\
86.00 \\
\text { EF; SE: } \\
75.00, \text { SP: } \\
43.00\end{array}$ \\
\hline $\begin{array}{l}\text { Nyns et al. }{ }^{30} \\
(2016)\end{array}$ & \multicolumn{2}{|c|}{$\begin{array}{l}\text { 17. Unclear about } \\
\text { split between } \\
\text { sets. }\end{array}$} & $\begin{array}{l}\text { Children and } \\
\text { adolescents }\end{array}$ & MRI & $\begin{array}{l}\text { Ventricular } \\
\text { volume- } \\
\text { try, using a } \\
\text { short-axis } \\
\text { cine stack }\end{array}$ & $\begin{array}{l}\text { Evaluate } \\
\text { feasibility, } \\
\text { accuracy } \\
\text { and labour } \\
\text { intensity } \\
\text { compared to } \\
\text { conventional } \\
\text { Simpson's } \\
\text { method }\end{array}$ & $\begin{array}{l}\text { Knowledge- } \\
\text { based }\end{array}$ & $\begin{array}{l}\text { EDV: } 82.00 \\
\text { ESV: } 93.00 \\
\text { EF: } 73.00\end{array}$ \\
\hline $\begin{array}{l}\text { Yang et al. }{ }^{13} \\
(2002)\end{array}$ & \multicolumn{2}{|c|}{$\begin{array}{l}106 \text { used for } \\
\text { both training and } \\
\text { testing. }\end{array}$} & $\begin{array}{l}\text { ECG from } \\
\text { database } \\
\text { (Nagoya } \\
\text { University } \\
\text { Hospital, } \\
\text { Nagoya, } \\
\text { Japan) }\end{array}$ & ECG & $\begin{array}{l}\text { ECG features: } \\
\text { waveforms, } \\
\text { and voltages } \\
\text { of upright } \\
\text { and negative } \\
\text { deflections }\end{array}$ & $\begin{array}{l}\text { Differentiate } \\
\text { between } \\
\text { ASD and } \\
\text { non-ASD }\end{array}$ & $\begin{array}{l}\text { Artificial } \\
\text { neural } \\
\text { network }\end{array}$ & $\begin{array}{l}\text { ACC: } 91.50 \\
\text { SE: } 91.40 \\
\text { SP: } 91.70\end{array}$ \\
\hline $\begin{array}{l}\text { Ruiz- } \\
\text { Fernandez } \\
\text { et al. }^{8}(2015)\end{array}$ & \multicolumn{2}{|c|}{$\begin{array}{l}2432 \text { used for } \\
\text { both training and } \\
\text { testing. }\end{array}$} & $\begin{array}{l}\text { Children } \\
\text { heart disease } \\
\text { database }\end{array}$ & $\begin{array}{l}\text { Classi- } \\
\text { fication } \\
\text { model }\end{array}$ & $\begin{array}{l}\text { Presurgical } \\
\text { and postsur- } \\
\text { gical data }\end{array}$ & $\begin{array}{l}\text { Classifying } \\
\text { the risk of } \\
\text { paediatric } \\
\text { cardiac } \\
\text { surgery }\end{array}$ & $\begin{array}{l}\text { Multilayer } \\
\text { Perceptron; } \\
\text { Radial Basis } \\
\text { Function; } \\
\text { Self- } \\
\text { organising } \\
\text { Map; } \\
\text { Decision } \\
\text { Tree }\end{array}$ & $\begin{array}{l}\text { 99.87; } \\
95.60 \\
81.79 \\
80.09\end{array}$ \\
\hline
\end{tabular}


Table 1 continued

\begin{tabular}{|c|c|c|c|c|c|c|c|c|}
\hline $\begin{array}{l}\text { First author } \\
\text { (year) }\end{array}$ & $\begin{array}{l}\mathrm{n} \\
\text { (training } \\
\text { set) }\end{array}$ & $\begin{array}{l}\mathrm{n} \\
\text { (test } \\
\text { set) }\end{array}$ & $\begin{array}{l}\text { Patient } \\
\text { population }\end{array}$ & $\begin{array}{l}\text { Category } \\
\text { for } \\
\text { analysis }\end{array}$ & $\begin{array}{l}\text { Data used for } \\
\text { analysis }\end{array}$ & $\begin{array}{l}\text { Primary } \\
\text { outcome }\end{array}$ & $\begin{array}{l}\text { Learning } \\
\text { algorithm }\end{array}$ & $\begin{array}{l}\text { Accuracy } \\
(\%)\end{array}$ \\
\hline $\begin{array}{l}\text { Ruiz et al. }{ }^{14} \\
\text { (2019) }\end{array}$ & \multicolumn{2}{|c|}{$\begin{array}{l}93 \text { patients. } \\
\text { Unclear about } \\
\text { split between } \\
\text { sets. }\end{array}$} & $\begin{array}{l}\text { Infants with } \\
\text { single-ventricle } \\
\text { physiology }\end{array}$ & $\begin{array}{l}\text { Pre- } \\
\text { diction } \\
\text { model }\end{array}$ & $\begin{array}{l}\text { Inpatient } \\
\text { data }\end{array}$ & $\begin{array}{l}\text { Predict } \\
\text { critical } \\
\text { events } \\
\text { early and } \\
\text { accurately }\end{array}$ & Naïve Bayes & $\begin{array}{l}\text { SE: } 84.00 \\
\text { SP: } 81.00\end{array}$ \\
\hline $\begin{array}{l}\text { Diller et al. }{ }^{15} \\
(2018)\end{array}$ & 8.015 & 2.004 & $\begin{array}{l}\text { Adult patients } \\
\text { under active } \\
\text { follow-up } \\
\text { in Royal } \\
\text { Brompton } \\
\text { Hospital, } \\
\text { London, UK }\end{array}$ & $\begin{array}{l}\text { Classi- } \\
\text { fication } \\
\text { model }\end{array}$ & $\begin{array}{l}\text { Patient data, } \\
\text { including } \\
\text { diagno- } \\
\text { sis, clinical } \\
\text { status, and } \\
\text { medication }\end{array}$ & $\begin{array}{l}\text { Categorise } \\
\text { patients in } \\
\text { diagnostic } \\
\text { and disease } \\
\text { complexity } \\
\text { subgroups }\end{array}$ & $\begin{array}{l}\text { Deep } \\
\text { Learning }\end{array}$ & 90.20 \\
\hline $\begin{array}{l}\text { Chiogna et } \\
\text { al. }{ }^{31} \text { (1996) }\end{array}$ & 457 & 114 & Neonates & $\begin{array}{l}\text { Classi- } \\
\text { fication } \\
\text { model }\end{array}$ & $\begin{array}{l}21 \text { ques- } \\
\text { tions based } \\
\text { on clinical } \\
\text { presentation, } \\
\text { blood gasses, } \\
\text { and imaging } \\
\text { modalities }\end{array}$ & $\begin{array}{l}27 \\
\text { congenital } \\
\text { heart } \\
\text { disease } \\
\text { classes }\end{array}$ & Decision tree & 59.00 \\
\hline
\end{tabular}

*Saint Paul, Minnesota, USA.

+Welch Allyn ${ }^{\circledast}$, Skaneateles Falls, New York, USA.

ACC: accuracy; ASD: atrial septal defect; BAV: bicuspid aortic valve; ccTGA: congenitally-corrected transposition of great arteries; CHD: congenital heart disease; CoA: coarctatio aortae; EDV: end-diastolic volume; EF: ejection fraction; ESV: end-systolic volume; MR: mitral regurgitation; PAH: pulmonary artery hypertension; SE: sensitivity; SP: specificity; TGA: transposition of great arteries.

Table 1 shows an overview of each selected article found in this search. No articles on $\mathrm{CT}$ in $\mathrm{CHD}$ patients were found during this search. $4,8,9,13-16,21-31$

\section{Patient Population}

In total, 15,244 patients were analysed: 10,354 adults (35\% male; $33 \%$ female; $32 \%$ no gender described; mean age of $33.30 \pm 13.00$ years), 1,858 children (>2 years old; mean age of 9.22 \pm 1.09 years $[42 \%$ of patients]; $58 \%$ no age described), and 4,099 were infants ( $<2$ years old; age not described). Diagnoses of CHD of varying complexity were made in 14,532 (95.33\%) patients and 712 (4.67\%) patients were included as a healthy control group.

\section{Learning Algorithms}

In the 18 analysed articles, 15 different Al algorithms were used. The most used technique was the artificial neural network (ANN) in four of the articles (22\%). Table 2 gives an overview of all techniques used in this review. Nine out of 18 articles analysed the use of $M L$ in heart sounds (50\%). The other articles analysed echocardiography $(n=3,17 \%), M R I(n=1,6 \%)$, ECG $(n=1,6 \%)$, as well as prediction or classification models ( $n=4,22 \%)$.

\section{Heart Sound Analysis}

Nine articles aimed to distinguish between pathological or innocent murmurs using ML on sound recordings from an electronic stethoscope.

The study by DeGroff et al. ${ }^{24}$ aimed to determine pathological from innocent murmurs using spectral resolution and frequency range as input. Using an ANN, they found high SP and SE (both $>90.0 \%)$. Sepehri et al..$^{25}$ also found high accuracy (93.6\%) using an ANN based on spectral and timing properties of the sound recordings of heart sounds of murmurs. The algorithm was trained on 60 normal and 60 pathological heart sound recordings. 


\begin{tabular}{|c|c|}
\hline $\begin{array}{l}\text { Support vector } \\
\text { machine (SVM) }\end{array}$ & $\begin{array}{l}\text { The SVM searches for the best separation line or decision boundary (also called the maximum } \\
\text { margin hyperplane) between two groups of data. The maximum margin is the equidistance between } \\
\text { the closest vectors of both groups. These two vectors are called the support vectors. The maximum } \\
\text { margin hyperplane is determined by the training dataset. Any new vector from the testing or } \\
\text { validation dataset will fall on one side of the hyperplane or the other; based on this, the vector is } \\
\text { sorted into the correct class. }{ }^{9,25}\end{array}$ \\
\hline $\begin{array}{l}\text { Decision tree } \\
\text { (DT) }\end{array}$ & $\begin{array}{l}\text { In a DT, the algorithm is dividing the data into different groups. During each separation, the algorithm } \\
\text { tries to maximise the number of vectors from a certain category. Rules for separation are generated } \\
\text { by following the path from branch to leaf; however, since a lot of paths are possible, it can reach } \\
\text { a considerable size. DT are not very powerful on their own but can be used in other methods that } \\
\text { leverage their simplicity. }\end{array}$ \\
\hline $\begin{array}{l}\text { Knowledge- } \\
\text { based }\end{array}$ & $\begin{array}{l}\text { The knowledge-based algorithm tries to reconstruct shapes of the heart based on anatomical } \\
\text { landmarks. The database already contains information of reconstructed 3D surface models of the } \\
\text { preferred anatomy. The algorithm will reconstruct the requested anatomy from a new patient based } \\
\text { on data out of the database. }{ }^{30}\end{array}$ \\
\hline $\begin{array}{l}\text { Arash-band } \\
\text { method }\end{array}$ & $\begin{array}{l}\text { Every heart disease has a discriminative frequency band, named the Arash-Band. The Arash-Band } \\
\text { is defined as the spectral energy band that provides maximum discrimination with respect to the } \\
\text { normal condition. The Arash-Band is calculated during the training phase, using statistical techniques } \\
\text { as the discriminating tools for the band selection. }{ }^{28}\end{array}$ \\
\hline $\begin{array}{l}\text { Linear } \\
\text { discriminant } \\
\text { analysis (LDA) }\end{array}$ & $\begin{array}{l}\text { The LDA tries to find a linear combination of features to separate between two or more classes. } \\
\text { The LDA has continuous independent variables (the features) and the class label as a continuous } \\
\text { dependent variable. }\end{array}$ \\
\hline $\begin{array}{l}\text { Hidden Markov } \\
\text { model (HMM) }\end{array}$ & $\begin{array}{l}\text { A Markov model can be used to calculate a probability for an observable event, an HMM also looks at } \\
\text { hidden events, such as part-of-speech tags. In an HMM there is a hidden Markov layer, which contains } \\
\text { a Markov chain. A Markov chain is a model that calculates the probabilities of sequences of random } \\
\text { variables. A Markov chain only takes into account the current state and does not account for any } \\
\text { previous state. }\end{array}$ \\
\hline $\begin{array}{l}\text { Self-organising } \\
\text { map (SOM) }\end{array}$ & $\begin{array}{l}\text { This algorithm represents competitive learning, all neurons compete to be the closest to the input } \\
\text { value. The Euclidian distance is used to measure similarities between the input value and each } \\
\text { neurons' weight in order to choose the winning neuron. Afterwards, the weight of the winner and its } \\
\text { neighbours is updated for the next input value. }\end{array}$ \\
\hline Naïve Bayes (NB) & $\begin{array}{l}\text { The NB assumes that every feature is independent of the value of any other feature. The classifier } \\
\text { is based on Bayes theorem, meaning the probability of A happening, given B has occurred is equal } \\
\text { to the probability of B happening, given A has occurred times the probability of A, divided by the } \\
\text { probability of B. The NB is an oversimplification of assumptions but tends to work quite well in } \\
\text { complex problems. }{ }^{14}\end{array}$ \\
\hline $\begin{array}{l}\text { Deep learning } \\
(\mathrm{DL})\end{array}$ & $\begin{array}{l}\text { Deep Learning refers to every algorithm with multiple layers, making it deep. In the article by Diller et } \\
\text { al. }{ }^{15} \text { it is referred to a combination of convolutional network and a dense network. A dense network is } \\
\text { a network in which the number of links between nodes is close to the maximal number of nodes. }{ }^{15}\end{array}$ \\
\hline $\begin{array}{l}\text { Artificial neural } \\
\text { network (ANN) }\end{array}$ & $\begin{array}{l}\text { The neural networks are made to mimic the neural networks in the brain. The neural network usually } \\
\text { consists of an input layer, one or more hidden layers, and an output layer. The input values represent } \\
\text { the dendrites going to a neuron, which then ends in the output signal, representing the axon. The } \\
\text { neuron determines if the sum of the input values is important and if they get passed along to the } \\
\text { output value. The neuron is represented by the so-called activation function. The weighted sum of } \\
\text { the input values is applied in the activation function (most common functions are the threshold, } \\
\text { sigmoid, rectifier, or hyperbolic tangent function). Every activation function has a different method } \\
\text { to determine how it will be activated. If the weighted sum is high enough, the signal will be passed } \\
\text { onto the output value. Every input value is connected to every hidden layer neuron, from which one } \\
\text { value is passed to the output layer neuron, after which one value is the output value. The output } \\
\text { value can be binary, categorical, or continuous. The predicted output value is compared to the actual } \\
\text { output value. Using a cost-function, the error between the output values is compared, this error is fed } \\
\text { back to the neuron, and the weights of the input are updated (this is called backpropagation). This } \\
\text { process is repeated for all the values of the training dataset. After which the final weights are applied } \\
\text { to the test or validation dataset.24,27 }\end{array}$ \\
\hline
\end{tabular}




\begin{tabular}{|l|l|}
\hline $\begin{array}{l}\text { Convolutional } \\
\text { neural network }\end{array}$ & $\begin{array}{l}\text { CNN have a similar algorithm to the ANN, however the input for a CNN is an image as to a value } \\
\text { in the ANN. The image gets down sampled by a feature detector (also known by kernel or filter), } \\
\text { which results in a feature map. The size of the feature detector determines the size of the feature } \\
\text { map. The bigger the feature detector, the smaller the feature map will be and the bigger the down- } \\
\text { sampling of the original image. Many feature maps will be created to obtain the first convolutional } \\
\text { layer, using different feature detectors. Trough training the algorithm determines how the feature } \\
\text { detectors should look to preserve important features from the original image. After the convolutional } \\
\text { layer, a rectified linear unit function is applied to remove all linearity since images themselves are } \\
\text { highly nonlinear. When making the feature maps, linearity can occur due to the down sampling. } \\
\text { Then a pooling layer has been applied. The pooling layer makes the image recognisable even if } \\
\text { the image has been tilted or shifted and makes overfitting less possible by reducing the size of the } \\
\text { convolutional layer. Lastly, a flattening layer conducts a similar function as the activation function } \\
\text { in the ANN. After the flattening layer, the output of this process will be used as an input for an } \\
\text { algorithm that is similar to the ANN. In the backpropagation not only are the weights adjusted, but } \\
\text { also the feature detectors, creating a more accurate down-sampling of the image. }\end{array}$ \\
\hline $\begin{array}{l}\text { Radial basis } \\
\text { function } \\
\text { networks (RBF) }\end{array}$ & $\begin{array}{l}\text { RBF is a type of ANN. The input layer and the hidden layer do not have associated weights. Each } \\
\text { neuron in the hidden layer represents an RBF. The neurons compute the Euclidean distance between } \\
\text { the synaptic weights vector and the input values. Over this distance the RBF is applied, which most } \\
\text { often is the Gaussian function. }\end{array}$ \\
\hline $\begin{array}{l}\text { Multi-layer } \\
\text { perceptron (MLP) }\end{array}$ & $\begin{array}{l}\text { The MLP is an example of feedforward ANN. In general, it refers to multiple layers of perceptrons } \\
\text { with threshold activation. }\end{array}$ \\
\hline
\end{tabular}

To evaluate the algorithm, it was tested with 60 either innocent or pathological murmurs to correctly identify first and second heart sounds. Other articles used multiple algorithms to distinguish between a pathological or innocent murmur, namely linear discriminant analysis, support vector machine, a combination between hidden Markov model and support vector machine, ANN, and the Arash-band. ANN was the most frequently used algorithm $(n=3,33 \%)$, and yielded the highest accuracy, SE, and SP.

\section{Echocardiographic Analysis}

Al algorithms were used on echocardiographic data to distinguish between structurally normal or pathological hearts, or to determine cardiac cavity volumes and function. The algorithm can be trained to detect change in echogenicity in the collected data, which can be seen in the wall of the heart. In this manner, Diller et al. ${ }^{4}$ found accuracy of $98 \%$ in distinguishing between transposition of the great arteries (TGA) after an atrial switch operation, congenitally corrected-TGA, and normal controls using a convolutional neural network (CNN) algorithm. The endocardial border was marked by two researchers and compared to the border marked by a CNN algorithm. A knowledge-based article written by Neukamm et al. ${ }^{29}$ only looked at SE and SP and found that making a 3D model out of the 2D echocardiogram data is feasible in $97 \%$ of cases; however, results for assessing the ejection fraction (EF) were unsatisfactory and MRI remains the method of choice.

\section{MRI}

In one of the articles by Nyns et al.,30 MRI was used as an input for knowledge-based reconstruction of the volume of the right ventricle after atrial switch operation in patients with a TGA. In a knowledge-based reconstruction, the input is compared to a database that contains information on the 3D model of the place of interest and tries to reconstruct based on this database. ${ }^{30}$ The knowledge-based reconstruction was compared to the gold standard, which is the Simpson's method. The Simpson's method is a geometric model in which the right ventricle is calculated based on the sum of a cylinder (base of the heart to the tricuspid valve). ${ }^{32}$ The accuracy of the end-diastolic volume (82\%), end-systolic volume (93\%), and EF (73\%) were compared. Knowledge-based reconstruction is a feasible, accurate, and fast method compared to the gold standard for measuring right ventricle volumes in patients after arterial switch operation. ${ }^{30}$ 


\section{Electrocardiogram Analysis}

One article was found using ML on ECG of patients with CHD. In this article by Yang et al., ${ }^{13}$ the authors aimed to distinguish atrial septum defect from patients with nonatrial septum defect and healthy controls' ECG. The QRS and $T$ wave measurements from lead I, lead II, and all precordial leads were used as input. A SE of $91.4 \%$ and SP of $91.7 \%$ was found, with an accuracy of $91.5 \%$ using an ANN.

\section{Classification Model}

In the classification and prediction models, the $M L$ algorithms were used to predict clinical deterioration, to classify surgical risk, or to classify the heart disease using patient characteristics. If the output of the network is categorical, it will make a prediction model. If the output has discrete values, the algorithm will do a classification of the data. ${ }^{33}$ Ruiz-Fernandez et al. ${ }^{8}$ found an accuracy of $99.9 \%$ in classifying the risk of mortality in paediatric surgery using the multilayer perceptron algorithm. The goal of this study was to develop a clinical decision support system to help cardiologists decide whether surgery was indicated. Ruiz et al. ${ }^{14}$ investigated early prediction of critical events in infants using a naïve Bayesian model. Thirty-four routinely collected data points, such as heart rate, $\mathrm{CO}_{2}$, and lactate, were used as input for the models. The model was able to detect future events up to 1 hour away with a SE of $84.0 \%$ and a SP of 81.0\%. Diller et al..$^{15}$ used DL techniques (statistical learning which extracts features from raw data) to categorise diagnostic group, disease complexity, and New York Heart Association (NYHA) class, with an accuracy of $90.2 \%$. In addition, they also estimated prognosis of the disease of adults with all types of CHD and to decide if patients needed to be discussed in the multidisciplinary team. Lastly, Chiogna et al. ${ }^{31}$ used a decision tree algorithm to classify neonates with CHD into 27 disease classes, compared to an expert opinion. Input data consisted of routinely clinical data acquired at birth, such as ECG data, $\mathrm{pO}_{2}$, heart size based on the chest X-ray, partial pressure of $\mathrm{CO}_{2}$, and oligemic lung fields. Accuracy of $59.0 \%$ was achieved.

\section{Discussion}

This review provides an overview of the possibilities of Al for patients with CHD. Although Al algorithms have been used for patients since 2001, relatively few articles have been published on this subject. However, Al algorithms are gaining popularity in healthcare and especially in cardiology. ${ }^{24}$ This is also demonstrated in this review since most articles are of relatively recent date (earliest dated 2015). In this review the authors found high SE and SP in most categories (echocardiographic data, ECG data, and in prediction/classification models), which means Al algorithms have great potential as an additional diagnostic tool in patients with CHD. However, the SE, SP, and accuracy are not yet high enough to be able to implement these algorithms safely in daily practice.

Most of the articles used ML on heart sounds, with high SP and SE. The highest accuracy (94\%) was found using the ANN algorithm. Heart sound analysis is noninvasive, inexpensive to perform, and remains an important diagnostic tool in both adults and children. Overall, the techniques that were used distinguished between healthy and pathological sounds only, which might be useful as a primary screening tool. Heart sound analysis in patients with acquired heart disease also showed high SE, SP, and accuracy. ${ }^{34}$ Ari et al. ${ }^{35}$ managed to distinguish between aortic insufficiency, aortic stenosis, atrial septal defect, mitral regurgitation, mitral stenosis, or normal heart sound with an accuracy of 92\%. These techniques can establish a diagnosis but do not yet determine the severity of the valve lesion. However, one could argue that heart sound analysis using ML should not be the main objective, as other noninvasive methods (echocardiography and cardiovascular MRI) are likely to be more informative if interpreted by $M L$ techniques. The technique could be used as a screening tool by general practitioners to distinguish who should be sent to the hospital for further check-up.

Learning algorithms on noninvasive cardiac imaging (echocardiographic and $\mathrm{MRI}$ ) shows a high accuracy when using a CNN algorithm, especially in the assessment of cardiac volumes. ${ }^{4} \mathrm{Al}$ algorithms have been used for echocardiographic imaging since 2006, but only started gaining popularity since 2012. Asch 
et al. ${ }^{36}$ trained a $\mathrm{ML}$ algorithm to automatically estimate the left ventricular EF on a database of $>50$ echocardiographic studies, including the apical 2- and 4-chamber views, and were compared to the left ventricular EF as assessed by the echocardiographist or cardiologist. The ML algorithm proved less sensitive (90\% versus $93 \%$ ), but more specific ( $92 \%$ versus $87 \%$ ), and accurate (92\% versus $89 \%$ ), which makes the algorithms highly feasible in daily practice. However, patients with CHD tend to develop problems in their right ventricle. Genovese et al. ${ }^{37}$ analysed 3D quantification of the right ventricle size and function in 56 patients receiving both cardiac magnetic resonance and 3D echocardiography exam on the same day. Echocardiographic volumes were analysed with a ML technique and compared with the cardiac MRI using the Bland-Altman and linear regression analyses. The automated $\mathrm{ML}$ analysis was correct in 18 patients (32\%) but needed corrections in the remaining 38 patients. Although an intraclass correlation coefficient of $97 \%$ could be reached for the end-diastolic volume, $98 \%$ for the endsystolic volume, and 95\% for the EF, the accuracy of a $M L$ algorithm remains strongly correlated with the image quality. It seems likely that with increasing image quality, $M L$ algorithms for its interpretation will become more reliable.

As with the echocardiography, cardiac MRI combined with $M L$ has been gaining popularity and is already being used in daily practice. Ruijsink et al. ${ }^{38}$ tried to analyse the cardiac magnetic resonance imaging using $D L$ algorithms to automate ventricular function assessment for both ventricles, and reached SE of $95 \%$, SP of $83 \%$, and an accuracy of $89 \%$. In the technique described by Nyns et al., ${ }^{30}$ the right ventricle was automatically analysed, but the key anatomical landmarks needed to be selected beforehand. More research is needed to evaluate if the $D L$ algorithm could also make this process quicker with comparable SE, SP, and accuracy.

Remarkably, the sole article on ECG in CHD patients dates from 2002, although a lot of $M L$ is conducted on ECG data in the general cardiac population $33,39-43$. Adult patients with $\mathrm{CHD}$ of 10 experience arrhythmias, which makes them a suitable group to use ML techniques with to predict events. ${ }^{44}$ However, the baseline ECG recordings of these patients often already has an abnormal appearance and differs between patients with the same congenital heart defect, further complicating the analysis of the ECG. In patients with acquired heart disease, the most analysed arrhythmia is atrial fibrillation. Using ML, ECG characteristics during sinus rhythm can be determined to establish the presence of an atrial fibrillation signature during sinus rhythm, with high SE (79\%), SP (80\%), and accuracy of (79\%). ${ }^{20}$ This algorithm could be used in patients with CHD as it seems suitable in left and right bundle branch block, premature ventricular contraction, atrial premature beat, and paced beat. Further research on ML ECG interpretation in patients with CHD is warranted and seems feasible.

ML can also be used to make prediction or classification models, which are used to determine in which group a specific outcome would fit. In patients with acquired heart disease the prediction models are mostly used to determine an outcome after surgery or to make a definitive risk model; however, these models perform poorly in predicting outcomes. ${ }^{45,46}$ The model by Ruiz et al. ${ }^{14}$ in 2016 gave a low accuracy when classifying different diagnoses of congenital heart defects based on a questionnaire. The model made by Ruiz-Fernandez et al. ${ }^{8}$ in 2019 could be used in clinical practice because of the high accuracy, but no SE or SP is given. If the SE, SP, or accuracy is low, more research must be carried out or alternative endpoints must be chosen. A solution could be found by comparing the results to human analysis; if it is better than the current gold standard, it could be implemented in clinical practice. However, an accuracy, SE, and SP above 95\% should be pursued before implementation is preferred.

The use of $\mathrm{Al}$ algorithms in cardiology has gained enormous interest in recent years and is predicted to grow even more in the upcoming years. In patients with acquired heart disease, $M L$ and $D L$ is already being used for imaging modalities and outcome prediction. In patients with $\mathrm{CHD}$, on the other hand, the authors found only 18 articles on learning algorithms. These algorithms have high potential in the population of patients with CHD. Cardiac evaluation in the hospital with ECG and imaging techniques are frequent and a great amount of data is generated from these patients. Moreover, patients with CHD are vulnerable to cardiac morbidity and mortality and often experience complications. Prediction of deterioration in these patients could save lives. 
There are a lot of different Al algorithms, with none being superior over the others for their specific task. The authors found that most techniques gave comparable SE, SP, and accuracy. It is more important to choose the right patient features or input data and perform preprocessing of the data to be used. ${ }^{47-49}$ Because a large number of different algorithms were used, it was difficult to compare them. It is important avoid deviation in the different algorithms to keep track of the focus: implementation in the clinical setting. In an ideal situation, the authors would like to have an algorithm that would be able to calculate the same values (in case of calculating ventricle volumes) as an imaging physician would. Bigger and more diverse datasets are needed to train the algorithms better and to be applicable to every patient in clinic. A limitation of current algorithms is that even though the accuracy, SE, and SP can be high, mistakes can still occur. This raises questions regarding the extent to which physicians should trust the algorithm and what safeguards are in place if the conclusion of the algorithm is incorrect. However, these questions are beyond the scope of the current review.

\section{CONCLUSION}

Al algorithms are increasingly applied in healthcare and draw a lot of attention given the large potential the technology promises. Results of recent studies on $\mathrm{Al}$ algorithms in patients with $\mathrm{CHD}$ indeed show promising results, as the algorithms aid analysis of ECG, cardiac imaging, and helps to predict outcomes. However, current data on Al algorithms in patients with CHD is still limited and larger scale studies are warranted to provide algorithms that could assist physicians better in the future with high SE, SP, and accuracy.

\section{References}

1. van der Bom $T$ et al. The changing epidemiology of congenital heart disease. Nat Rev Cardiol. 2011;8(1):50-60.

2. van der Bom T et al. The prevalence of adult congenital heart disease, results from a systematic review and evidence based calculation. Am Heart J. 2012;164(4):568-75.

3. Schwerzmann $M$ et al. Challenges of congenital heart disease in grown-up patients. Swiss Med Wkly. 2017;147:w14495.

4. Diller GP et al. Utility of machine learning algorithms in assessing patients with a systemic right ventricle. Eur Heart J Cardiovasc Imaging. 2019;20(8):925-31.

5. Schultz KE et al. Extended cardiac ambulatory rhythm monitoring in adults with congenital heart disease: arrhythmia detection and impact of extended monitoring. Congenit Heart Dis. 2019;14(3):410-8.

6. Egbe $A C$ et al. Role of QRS fragmentation for risk stratification in adults with tetralogy of Fallot. J Am Heart Assoc. 2018;7(24):e010274.

7. Saleh $A$ et al. Predictive value of P-wave and QT interval dispersion in children with congenital heart disease and pulmonary arterial hypertension for the occurrence of arrhythmias. J Saudi Heart Assoc. 2019;31(2):57-63.

8. Ruiz-Fernández D et al. Aid decision algorithms to estimate the risk in congenital heart surgery. Comput Methods Programs Biomed.

\section{6;126(C):118-27}

9. Gharehbaghi A et al. A decision support system for cardiac disease diagnosis based on machine learning methods. Stud Health Technol Inform. 2017;235:43-7.

10. Hannun AY et al. Cardiologistlevel arrhythmia detection and classification in ambulatory electrocardiograms using a deep neural network. Nat Med. 2019;25(1):65-9.

11. Faust $\mathrm{O}$ et al. Deep learning for healthcare applications based on physiological signals: a review. Comput Methods Programs Biomed. 2018;161:1-13.

12. Hamet P, Tremblay J. Artificial intelligence in medicine. Metabolism. 2017;69S:S36-40.

13. Yang $S$ et al. Use of an artificial neural network to differentiate between ECGs with IRBBB patterns of atrial septal defect and healthy subjects. Med Inform Internet Med. 2002:27(1):49-58.

14. Ruiz VM et al. Early prediction of critical events for infants with single-ventricle physiology in critical care using routinely collected data. J Thorac Cardiovasc Surg. 2019;158(1):234-43.e3.

15. Diller GP et al. Machine learning algorithms estimating prognosis and guiding therapy in adult congenital heart disease: data from a single tertiary centre including 10019 patients. Eur Heart J. 2019;40(13):1069-77.
16. Pereira $\mathrm{F}$ et al. Automated detection of coarctation of aorta in neonates from two-dimensional echocardiograms. J Med Imaging. 2017;4(1):014502.

17. Haseena $\mathrm{HH}$ et al. Classification of arrhythmia using hybrid networks. J Med Syst. 2011;35(6):1617-30.

18. Kim J et al. Algorithm for classifying arrhythmia using extreme learning machine and principal component analysis. Conf Proc IEEE Eng Med Bio Soc. 2007;2007:3257-60. doi:10.1109/ IEMBS.2007.4353024.

19. Yang $W$ et al. Automatic recognition of arrhythmia based on principal component analysis network and linear support vector machine. Comput Biol Med. 2018;101:22-32.

20. Attia $\mathrm{Zl}$ et al. An artificial intelligenceenabled ECG algorithm for the identification of patients with atrial fibrillation during sinus rhythm: a retrospective analysis of outcome prediction. Lancet. 2019;394(10201):861-7.

21. Elgendi $M$ et al. The unique heart sound signature of children with pulmonary artery hypertension. Pulm Circ. 2015;5(4):631-9.

22. Gharehbaghi A et al. A novel method for screening children with isolated bicuspid aortic valve. Cardiovasc Eng Technol. 2015;6:546-56.

23. Elgendi $M$ et al. The voice of the heart: vowel-like sound in pulmonary artery hypertension. Diseases. 2018;6(2):26. 
24. DeGroff CG et al. Artificial neural network-based method of screening heart murmurs in children. Circulation. 2001;103(22):2711-6.

25. Sepehri AA et al. A novel method for pediatric heart sound segmentation without using the ECG. Comput Methods Programs Biomed. 2010;99(1):43-8.

26. Thompson WR et al. Artificial intelligence-assisted auscultation of heart murmurs: validation by virtual clinical trial. Pediatr Cardiol. 2019;40(3):623-9.

27. Bhatikar SR et al. A classifier based on the artificial neural network approach for cardiologic auscultation in pediatrics. Artif Intell Med. 2005;33(3):251-60.

28. Sepehri AA et al. An intelligent phonocardiography for automated screening of pediatric heart diseases. J Med Syst. 2016;40(1):16

29. Neukamm C et al. Right ventricular volumes assessed by echocardiographic three-dimensional knowledge-based reconstruction compared with magnetic resonance imaging in a clinical setting. Congenit Heart Dis. 2014;9(4):333-42.

30. Nyns ECA et al. Evaluation of knowledge-based reconstruction for magnetic resonance volumetry of the right ventricle after arterial switch operation for dextro-transposition of the great arteries. Int J Cardiovasc Imaging. 2016;32(9):1415-23.

31. Chiogna $M$ et al. An empirical comparison of expert-derived and data-derived classification trees. Stat Med. 1996;15(2):157-69.

32. Folland ED et al. Assessment of left ventricular ejection fraction and volumes by real-time, twodimensional echocardiography. A comparison of cineangiographic and radionuclide techniques. Circulation. 1979;60(4):760-6.

33. Chowdhury DR et al. An artificia neural network model for neonatal disease diagnosis. Int J Artif Intell Expert Syst. 2011;2(3):96-106.

34. Uğuz H. A biomedical system based on artificial neural network and principal component analysis for diagnosis of the heart valve diseases. J Med Syst. 2012;36(1):61-72.

35. Ari S et al. Detection of cardiac abnormality from PCG signal using LMS based least square SVM classifier. Expert Syst Appl. 2010;37(12);8019-26

36. Asch FM et al. Automated echocardiographic quantification of left ventricular ejection fraction without volume measurements using a machine learning algorithm mimicking a human expert. Circ Cardiovasc Imaging. 2019;12(9):e009303.

37. Genovese D et al. Machine learning-based three-dimensional echocardiographic quantification of right ventricular size and function: validation against cardiac magnetic resonance. J Am Soc Echocardiogr. 2019;32(8):969-77.

38. Ruijsink B et al. Fully automated, quality-controlled cardiac analysis from CMR: validation and large-scale application to characterize cardiac function. JACC CardiovasC Imaging. 2020;13(3):684-95.

39. Özbay $Y$ et al. A fuzzy clustering neural network architecture for classification of ECG arrhythmias. Comput Biol Med. 2006:36(4):376-88

40. Rodriguez-Sotelo JL et al. Unsupervised feature selection in cardiac arrhythmias analysis. Poster
FrBPo01.27. Annual International Conference of the IEEE Engineering in Medicine and Biology Society, 3-6 September, 2009.

41. Cubanski $D$ et al. A neural network system for detection of atrial fibrillation in ambulatory electrocardiograms. J Cardiovasc Electrophysiol. 1994;5(7):602-8.

42. Özbay Y. A new approach to detection of ECG arrhythmias: complex discrete wavelet transform based complex valued artificial neural network. J Med Syst. 2009;33(6):435-45.

43. Chakroborty S. Accurate arrhythmia classification using auto-associative neural network. Conf Proc IEEE Eng Med Biol Soc. 2013;2016:4247-50. doi:10.1109/EMBC.2013.6610483.

44. Tsipouras MG et al. An arrhythmia classification system based on the RR-interval signal. Artif Intell Med. 2005;33(3):237-50.

45. Lopes RR et al. Value of machine learning in predicting TAVI outcomes. Neth Heart J. 2019;27(9):443-50.

46. Maeno $\mathrm{Y}$ et al. A highly predictive risk model for pacemaker implantation after TAVR. JACC CardiovasC Imaging. 2017;10(10 Pt A):1139-47.

47. Kaya $Y$ et al. Effective ECG beat classification using higher order statistic features and genetic feature selection. Biomed Res. 2017:28(17):7594-603.

48. Zhu J et al. Feature extraction from a novel ECG model for arrhythmia diagnosis. Biomed Mater Eng. 2014;24(6):2883-91.

49. Asgari S et al. Automatic detection of atrial fibrillation using stationary wavelet transform and support vector machine. Comput Biol Med. 2015;60:132-42. 